Cardiology 1996;87:I-VI

\title{
Contents, Vol. 87, 1996
}

\section{Editorial Assistant}

J.S. Frank, Tucson, Ariz.

\section{Editorial Board}

Section 'General Cardiology'

H.J.C. Swan, Beverly Hills, Calif. (SH)

E.A. Amsterdam, Sacramento, Calif.

P.F. Cohn, Stony Brook, N.Y.

M.H. Crawford, Albuquerque, N. Mex.

J.E. Dalen, Tucson, Ariz.

P.C. Deedwania, Fresno, Calif.

R.L. Frye, Rochester, Minn.

V. Fuster, New York, N.Y.

B.J. Gersh, Washington, D.C.

T.H. Haghfelt, Odense

H. Just, Freiburg

E. Kaplinsky, Tel Hashomer

C.V. Leier, Columbus, Ohio

B.S. Lewis, Haifa

R.P. Lewis, Columbus, Ohio

B. McCallister, Jr., Ann Arbor, Mich.

I.S. Ockene, Worcester, Mass.

R.A. O'Rourke, San Antonio, Tex.

J.A. Paraskos, Worcester, Mass.

N. Rehnquist, Stockholm

L.E. Ryden, Stockholm

R.C. Schlant, Atlanta, Ga.

J.M. Sullivan, Memphis, Tenn.

K. Thygesen, Aarhus

N.K. Wenger, Atlanta, Ga.

J.T. Willerson, Houston, Tex.

R.G. Williams, Los Angeles, Calif.

Section 'General Cardiology,

Basic Research'

H. Taegtmeyer, Houston, Tex. (SH)

S. Haunsø, Copenhagen

T.W. Smith, Boston, Mass. 
Section 'Arrhythmias, Electro-physiology, and Electrocardiography' R.J. Myerburg, Miami, Fla. (SH) S.K.S. Huang, Worcester, Mass. E.N. Prystowsky, Indianapolis, Ind. J.N. Ruskin, Boston, Mass. D.M. Steinhaus, Kansas City, Mo. D.P. Zipes, Indianapolis, Ind.

Section 'CardiovascularSurgery' L.H. Cohn, Boston, Mass. J.J. Collins, Jr., Boston, Mass. T.J. Vander Salm, Worcester, Mass.

Section 'Catheterization and Interventional Cardiology' L.D. Hillis, Dallas, Tex. (SH) P.C.

Block, Portland, Oreg. B. Carabello, Charleston, S.C. S. Goldberg, Philadelphia, Pa. E.J. Topol, Cleveland, Ohio

Section 'Clinical Pharmacology' WJ. Remme, Rotterdam (SH) J.S. Karliner, San Francisco, Calif. A. Schneeweiss, Bad Schwalbach B.N. Singh, Los Angeles, Calif.

Section 'Coronary Care'

G.S. Francis, Minneapolis, Minn. (SH)

K. Chatterjee, San Francisco, Calif.

R.C. Pasternak, Boston, Mass.

R. Roberts, Houston, Tex.

Section 'Diagnostic Cardiology' G.A. Beller, Charlottesville, Va. (SH) J.S. Borer, New York, N.Y. A.N. De Maria, San Diego, Calif. RE. Kerber, Iowa City, Iowa J. Maddahi, Los Angeles, Calif. J.V. Nixon, Richmond, Va. M.D. Osbakken, Philadelphia, Pa. G.M. Pohost, Birmingham, Ala. N. Reichek, Pittsburgh, Pa. J.L. Ritchie, Seattle, Wash. B.L. Zaret, New Haven, Conn. Section 'Epidemiology and Prevention' R. Goldberg, Worcester, Mass. (SH) M. Kornitzer, Bruxelles

Section 'Pathology'

W.C. Roberts, Dallas, Tex. (SH)

H. Cuénoud, Worcester, Mass.

(SH): Section Head

Left ventricular hypertrophy 153,429

- relaxation 71

- wall motion 91

ventriculography 365 Lipid lowering therapy 497 Lipoprotein(a) 18 Lipoproteins 453, 497 Longterm prognosis 529 Low flow states 379 Lyme borreliosis 76 Lymphoma 566

Macrophages 458 Mechanical prosthesis 212 Medtronic Intact 212 MESAM-IV 492 Mevalonate pathway 458 Migration 458 Mild heart failure 147 Mitral flow 560

- pattern 205

stenosis 112,476

valve 335

- prolapse 374

- surgery 98 Moexipril 313 Morbidity 423 Mortality 396, 423, 502 Myocardial function 147

infarction $18,91,104,230,423$

injury 392

ischemia 134

-, silent 240

metabolism 516

perfusion defect 235

pH 516 
- $\quad$ scintigraphy 260

Myocarditis 79, 189

Myocardium 294

Natriuresis 46 Natriuretic peptides, brain,

atrial 12 Necrosis 294 Neurofibromatosis 1300

New York Heart Association Classification 443

- $\quad$ - - - functional class

250 Non-AMI 331 Noninvasive method 415 Normal coronary angiography 361

Obesity 347 Outflow velocity 537 Oxygen free radicals 18

Pwave 343 Parasympathetic activity 119

- $\quad$ nervous system 28

Percutaneous transluminal

coronary angioplasty 216 Plaque 384 Plasma hormones 402 Postmyocardial infarction

syndrome 67 Pregnancy 361 Pressure gradient(s) 212,545

overload hypertrophy 436 Primary antiphospholipid antibody syndrome 354

hypertension 119 Prognosis 60, 141 Prognostic variable 481 Proliferation 458 Propofol,

electrophysiological

effects 319 Pseudonormalization 560 Pulmonary artery 263

embolism 169,279

scintigraphy 331

venous flow 224 Pulsed Doppler 560

- echocardiography 153

Q waves, absence 358 QRS complex 125

- $\quad$ variance 161

QT interval 91

Quinidine 129

Rabbits 294

Radiofrequency ablation 33, 392

energy 42 Radionuclide angiography 347

ventriculography 250 Reactive hyperemia 216 Redistribution imaging 235 Regression analysis

481 Regurgitation, animal model

276 Relaxation abnormality 436 Renal neutral endopeptidase 46

- $\quad$ transplant 257

Right ventricular endomyocar-dial biopsy 189

- strain 279 Risk factors 453

stratification 104

Scintigraphy 82

-, resting reinjection 235

Serial ECG changes 365

Serum lipids 524

Severe left ventricular dysfunction 443

Sex 396

Shunt 263

Silent myocardial ischemia 283

Sleep apnea syndrome 492

Smoke-like echoes 379 
Smooth muscle cells 23, 458

Spatial velocity electrocardiogram 129

SPECT imaging 134

ST segment 125

Stunned myocardium 91

Sudden death 481

Supraventricular tachycardia 42,392

Surgery 325

Surgical closed commissu-rotomy 450

Survival 250

Sympathetic nervous system 28

Syncope 28,76, 177

Systolic function 287

201T1 scintigraphy 240 Takayasu's arteritis 303 Thallium-201 134,235 Three-dimensional echocardiography 552

reconstruction 335

ultrasound 335 Thrombolysis 384 Thrombolytic therapy 354 Thrombomodulin 303 Thrombus

379,384

-, right heart 169

Tolerability 54

Transesophageal echocardiography $224,335,379,450$

Transmitral Doppler 287

Transplantation 469

Traumatic coronary artery fistula 86

Treadmill exercise test 244

Treatment 230

Tricuspid regurgitation 86

Triiodothyronine 509

Trypanosomiasis, South American 481

Tubbs dilator 450

Tumor necrosis factor 476

Ultrasonic imaging 335

Vectorcardiogram 129 Velocity pattern, left ventricular inflow 112

- $\quad$-, pulmonary venous flow

112 Ventricular depolarization 129

fibrillation 200

tachycardia 82, 200

-, idiopathic 33 Volumetry 552

Wall motion index 250 Weber classification 443

$\mathrm{X}$ ray, chest 181

574

Subject Index Vol. 87, 1996

S. Karger

Medical and Scientific Publishers Basel · Freiburg · Paris · London New York · New Delhi ·

Bangkok Singapore $\cdot$ Tokyo $\cdot$ Sydney 


\section{Drug Dosage}

The authors and the publisher have exerted every effort to ensure that drug selection and dosage set forth in this text are in accord with current recommendations and practice at the time of publication. However, in view of ongoing research, changes in government regulations, and the constant flow of information relating to drug therapy and drug reactions, the reader is urged to check the package insert for each drug for any change in indications and dosage and for added warnings and precautions. This is particularly important when the recommended agent is a new and/or infrequently employed drug.

All rights reserved.

No part of this publication may be translated into other languages, reproduced or utilized in any form or by any means, electronic or mechanical, including photocopying, recording, microcopying, or by any information storage and retrieval system, without permission in writing from the publisher or, in the case of photocopying, direct payment of a specified fee to the Copyright Clearance Center (see 'Information for Readers and Subscribers').

(C) Copyright 1996 by S. Karger AG, P.O. Box, CH-4009 Basel (Switzerland) Printed in Switzerland on acid-free paper by Thür AG Offsetdruck, Pratteln

Contents Vol. 87, 1996

\section{CARDIOLOGY}

No. 1

Review

Prevention of Coronary Heart Disease in Clinical Practice:

A Commentary on Current Treatment Patterns in Six European

Countries in Relation to Published Recommendations

Shepherd, J.; Pratt, M. (Glasgow/Epsom)

General Cardiology

6 Effects of Intravenous Disopyramide on Coronary

Hemodynamics and Vasodilator Reserve in Hypertrophic Obstructive Cardiomyopathy

Hongo, M.; Nakatsuka, T.; Takenaka, H.; Tanaka, M.; Watanabe, N.; Yazaki, Y.; Sekiguchi, M. (Matsumoto)

12 Brain and Atrial IMatriuretic Peptides in Patients with Ischemic Heart Disease with and without Heart Failure

Arad, M.; Elazar, E.; Shotan, A.; Klein, R.; Rabinowitz, B. (Tel-Aviv)

18 Lipoprotein(a) and Oxygen Free Radicals in Survivors of Acute Myocardial Infarction:

Effects of Captopril

Søgaard, P.; Klausen, I.C.; Rungby, J.; Faergeman, O.; Thygesen, K. (Aarhus)

General Cardiology, Basic Science

Diagnostic and Noninvasive Cardiology

71 Left Atrial Appendage Blood Flow Determined by Transesophageal Echocardiography in Patients with Complete Atrioventricular Block

Lin, J.-M.; Lin, J.-L.; Chen, J.-J.; Li, Y.-H.; Huang, J.-J.; Tseng, Y.-Z. (Taipei)

Case Reports

76 Common Form of Lyme Borreliosis Carditis - Complete Heart Block with Syncope: Report on 3 Cases

Vasiljevic, Z.; Dmitrovic, R.i Naumovic, Z.; Ostojic, M.; Radosavljevic, M.; Karadzic, A.; Prostran, M.; Colic, M. (Belgrade) 79 Echocardiographic Follow-Up of Diphtheric Myocarditis Groundstroem. K.W.E.; Molnar, G.; Lumio, J. (Tampere) 
82 Sustained Nonischemic Ventricular Tachycardia during Dobutamine Stress Echocardiography Madu, E.C.; Price, A.; Harris, T.; Badran, H.; Rouse, C; Ramanathan, K.B. (Memphis, Tenn.) 86 Late Complications in Traumatic Coronary Artery Fistula: Report of a Case Requiring Surgical Repair after 8 Years

Shimabukuro, M,; Shinzato, T.; Yoshida, H; Nagamine, F.; Takasu, N.; Koja, K. (Okinawa) Letter to the Editor

23 Presence of Contractile-Type Smooth Muscle Cells in the Endocardium

Suzuki, T.; Aikawa, M; Kuro-o, M.; Watanabe, M.; Kimura, K.; Yazaki, Y.; Nagai, R. (Tokyo) 90 Amiodarone and Reversible Benign Intracranial Hypertension

Ahmad, S. (Fairmont, W. Va.)

Arrhythmias, Electrophysiology and Electrocardiography

No. 2

28 Power Spectral Analysis of Heart Rate Variability during

Upright Tilt Test: A Comparison of Patients with Syncope and Normal Subjects

Boulos, M.; Barren, S.; Nicolski, E.; Markiewicz, W. (Haifa)

33 Electropharmacologic Characteristics and Radiofrequency Catheter Ablation of Sustained Ventricular Tachycardia in Patients without Structural Heart Disease

Lee, S.-H.; Chen, S.-A.; Tai, C.-T.; Chiang, C.-E.; Wu, J.-T.; Cheng, C.-C; Chiou, C.-W.; Ueng, K.-W.; Wang, S.-P.; Chiang, B.N.; Chang, M.-S. (Taipei/Kaohsiung)

42 Does the Baseline Impedance Measurement during

Radiofrequency Catheter Ablation Influence the Likelihood of an Impedance Rise?

Wagshal, A.B.; Pires, L.A.; Bonavita, G.J.; Mittleman, R.S.; Huang, S.K.S. (Worcester, Mass.)

Clinical Pharmacology

46 Effects of Renal Neutral Endopeptidase Inhibition on Sodium Excretion, Renal

Hemodynamics and Neurohormonal Activation in Patients with Congestive Heart Failure

Kimmelstiel, CD.; Perrone, R.; Kilcoyne, L.; Souhrada, J.; Udelson, J.; Smith, J.; de Bold, A.;

Griffith, J.; Konstam, M.A. (Boston, Mass./Groton, Conn./Ottawa)

54 Tolerability and Efficacy of Antihypertensive Treatment with Cilazapril in General Practice

Rosenthal, J.R.; Osowski, U. (Ulm/Darmstadt)

Coronary Care

60

Long-Term Risk of Death, Cardiac Events and Recurrent Chest Pain in Patients with Acute

Chest Pain of Different Origin

Launbjerg, J.; Fruergaard, P.; Hesse, B.; Jørgensen, F.; Elsborg, L.; Petri, A.

(Hillerød/Copenhagen)

67

Antimitochondrial Antibodies after Acute Myocardial Infarction

Schifter, T.; Zahavi, I.; Moroz, C. (Petah-Tiqva)

Noninvasive and Diagnostic Cardiology

91 The Deeper the Negativity of the T Waves Recorded, the

Greater Is the Effectiveness of Reperfusion of the Myocardium

Nakajima, T.; Kagoshima, T.; Fujimoto, S.; Hashimoto, T,; Dohi, K. (Kashihara) 
98 Restoration of Mechanical Atrial Function after Electrical Cardioversion of Chronic Atrial Fibrillation in Patients after Surgical Treatment of Mitral Valve Disease - Hemodynamic Effects and Prognostic Value of Maintenance of Sinus Rhythm

Szyszka, A.; Trojnarska, O.; Paluszkiewicz, L.; Ciesliński, A.; Ponizyński, A. (Poznan)

104 Reduced Beat-to-Beat Changes of Heart Rate: An Important Risk Factor after Acute Myocardial Infarction

Reinhardt, L.; Mäkijärvi, M.; Fetsch, T.; Martinez-Rubio, A.; Böcker, D.; Block, M.; Borggrefe, M.; Breithardt, G. (Münster)

112 Transesophageal Pulsed Doppler Echocardiographic Study of Pulmonary Venous Flow in Mitral Stenosis

Tabata, T.; Oki, T,; Fukuda, N.; Iuchi, A.; Kawano, T.; Manabe, K; Tanimoto, M.; Kageji, Y.; Sasaki, M.; Hama, M.; Ito, S. (Tokushima)

119 Parasympathetic Withdrawal Precedes Spontaneous Blood Pressure Elevations in Women with Primary Hypertension

Dabrowska, B.; Dabrowski, A.; Skrobowski, A. (Warsaw)

125 Predicting Postinfarction Left Ventricular Dysfunction Based on the Configuration of the QRS Complex and ST Segment in the Initial ECG of Patients with a First Anterior Wall Myocardial Infarction

Hasdai, D.; Porter, A.; Birnbaum, Y.; Strahilevitz, J.; Sclarovsky, S. (Petah Tikva)

129 Heterogeneous Effect of Quinidine on the Ventricular Depolarization Process Assessed by the Spatial Velocity Electrocardiogram of the QRS Complex. Preliminary Report of a New Investigative Method

Fareh, S.; Arnaud, P.; Fayn, J.; Nony, P.; Girard, P.; Haugh, M.; Girard, I.; Ferry, S.; Boissel, J.P.; Rubel, P. (Lyon)

\section{KARGER}

E-Mail karger@karger.ch Fax+41 613061234 http://www.karger.ch

C1996S. KargerAG, Basel

The list of contents is available at: http://www.karger.ch/journals/car/carcont.htm

III

134 Patterns of Use and Clinical Utility of Exercise Thallium-201 Single Photon EmissionComputed Tomography in a Community Hospital

McClellan, J.R.; Dugan, T.M.; Heller, G.V. (Philadelphia, Pa./Erie, Pa./Hartford, Conn.)

141 Clinical Significance of Intracavitary Spontaneous Echo Contrast in Patients with Dilated

Cardiomyopathy

Shen, W.F.; Tribouilloy, C; Rida, Z.; Peltier, M,; Choquet, D.; Rey, J.-L.; Lesbre, J.-P. (Amiens)

147 Cardiopulmonary Exercise Response in Patients with Left

Ventricular Dysfunction or Heart Failure: A Noninvasive Study by Gas Exchange and Impedance Cardiography Monitoring

Romano, M.; Monteforte, I.; Cardei, S.; Lerro, A.; Celano, G.; Mazza, A.; Capaldo, M.; Paglia, N.; Campopiano, A.; Lembo, G.; Trimarco, B.; Condorelli, M. (Napoli)

153 Acute Filling Pattern Changes of the Failing Left Ventricle after Captopril as Related to Ventricular Structure

Barbier, P.; Tamborini, G.; Alioto, G.; Pepi, M. (Milano)

161 Beat-to-Beat QRS Amplitude Variability during Dobutamine Infusion in Patients with Coronary Artery Disease 
Hagerman, I.; Nowak, J.; Svedenhag, J,; Nyquist, O.; Sylvén, C. (Huddinge)

169 Floating Right Heart Thrombi and Pulmonary Embolism: Diagnosis, Outcome and Therapeutic Management

Chapoutot, L.; Nazeyrollas, P.; Metz, D.; Maes, D.; Maillier, B,; Jenesseaux, C; Elarts, J.

(Reims)

No. 3

Obituary

175 Lewis Dexter, MD

1910-1995

Dalen, J.E. (Tucson, Ariz.)

General Cardiology

177 Syncope in Dilated Cardiomyopathy Is a Predictor of Sudden Cardiac Death

Fruhwald, F.; Eber, B,; Schumacher, M.; Zweiker, R.; Watzinger, N.; Klein, W.W. (Graz)

181 Factors Predicting Maintenance of Sinus Rhythm after Direct Current Cardioversion of

Atrial Fibrillation and Flutter: A Reanalysis with Recently Acquired Data

Arnar, D.O.; Danielsen, R. (Reykjavik)

189 Increased Serum Levels of Circulating Intercellular Adhesion Molecule-1 in Patients with Myocarditis

Toyozaki, T.; Saito, T.; Takano, H,; Mori, H.; Kikuchi, T.; Karaki, A.; Iijima, Y.; Nakamura, Y.; Masuda, Y. (Chiba/Kanagawa)

194 Changes in Plasma Cholesterol Levels after Hospitalization for Acute Coronary Events

Brugada, R.; Wenger, N.K.; Jacobson, T.A.; Clark, W.S.; Cotsonis, G; Iglesias, A. (Atlanta, Ga.)

Arrhythmias, Electrophysiology and Electrocardiography

200 Relationship between Autonomic Nervous System Test Results, Ejection Fraction and

Inducibility of Sustained Ventricular Arrhythmias by Means of Electroph $\gamma$ siological Studies

Fuenmayor, A.J.; Rosales, J.G.; Fuenmayor, A.M. (Mérida)

205 Restoration of Atrial Function after Atrial Fibrillation of Different Etiological Origins

Mattioli, A.V.; Tarabini Castellani, E,; Vivoli, D.; Molinari, R.; Mattioli, G. (Modena)

Cardiac Surgery

212 Hemod $\gamma$ namic Comparison of Medtronic Intact Bioprostheses and Bileaflet Mechanical

Prostheses in Aortic Position

Ricou, F.; Brun, A.; Lerch, R. (Geneva)

Catheterization and Interventional Cardiology

216 A Mechanism of Ischemic Preconditioning during Percutaneous Transluminal Coronary

Angioplasty

Inoue, T.; Fujito, T.; Hoshi, K.; Sakai, Y.; Yamaguchi, H.; Takayanagi, K.; Morooka, S,;

Takabatake, Y. (Saitama)

Catheterization and Hemodynamics

224 Relationship of Pulmonary Venous Flow Pattern to Mean Left Atrial Pressure and Phasic

Pressure Change

Lin, J.-M.; Li, Y.-H.; Hsu, K.-L.; Hwang, J.-J.; Tseng, Y.-Z. (Taipei)

Coronary Care

230 Treatment of Patients with Acute Myocardial Infarction in Relation to Gender

Karlson, B.W.; Hartford, M.; Herlitz, J. (Göteborg)

Noninvasive and Diagnostic Cardiology

235 Persistent Thallium-201 Defect: Can Clinical, Electro- 
cardiographic and Exercise Hemodynamic Variables Predict Defect Normalization with Reinjection?

Shammas, N.W.; Schwartz, R.G.; Pomerantz, R.M.; Murphy, G.W.; Hall, W.J. (Rochester, N.Y.) 240 Predictive Value of Sequential Testing in Screening for Silent Myocardial Ischemia in Asymptomatic Middle-Aged Men (The ECCIS Project)

Antoniucci, D.; Seccareccia, F.; Menotti, A.; Prati, P.L.; Rovelli, F.; Fazzini, P.F.

(Florence/Rome/Milano)

244 Dobutamine Stress Echocardiography for Detecting Coronary Artery Disease

Wu, C.-C; Ho, Y.-L.; Kao, S.-L.; Chen, W.-J.; Lee, C.-M.; Chen, M.-F.; Liau, C.-S.; Lee, Y.-T. (Taipei)

250 Prognostic Value of Echocardiography in 190 Patients with Chronic Congestive Heart

Failure. A Comparison with New York Heart Association Functional Classes and Radionuclide Ventriculography

Kühn Madsen, B.; Videbæk, R,; Stokholm, H.; Spange Mortensen, L.; Fischer Hansen, J. (Copenhagen/Arhus)

Case Reports

257 Managing Acute Myocardial Infarction in a Renal Transplant Recipient

Conte, F.J.; Korr, K.S.; Katz, A.S.; Sadaniantz, A. (Providence, R.I.)

260 Treatment of Anomalous Origin of the Left Coronary Artery from the Pulmonary Artery in Adulthood

Christensen, E.D.; Johansen, J.B.; Thayssen, P.; Andersen, P.E.; Alstrup, P. (Odense)

263 Congenital Coronary Artery Fistulae Arising from Bilateral Coronary Arteries and Emptying into Both Pulmonary Artery and Left Ventricle: A Rare Presentation

Nawa, S.; Miyachi, Y.; Toshino, N.; Shiba, T.; Hayashi, K.; Tamesue, K.; Shimizu, N.

(Okayama/Niihama)

Letters to the Editor

267 Importance of Angiotensin-Converting Enzyme Inhibitors in

Myocardial Infarction and Congestive Heart Failure:

Implications for Clinical Practice

Cheng, T.O. (Washington, D.C.)

268 False-Positive Cardiac Troponin T Levels in Chronic

Hemodialysis Patients

Escalon, J.C.; Wong, S.S. (Houston, Tex.)

270 Nomenclature Problems in Modern Cardiology

Cheng, T.O. (Washington, D.C.)

IV

Cardiology Vol. 87, 1996

Contents

No. 4

Case Reports

General Cardiology

271 Improved Exercise Tolerance following Enhanced External Counterpulsation: Cardiac or Peripheral Effect? 
Lawson, W.E.; Hui, J.C.K.; Zheng, Z.S.; Burger, L,; Jiang, L.; Lillis, O.; Oster, Z.; Soroff, H.; Cohn, P.F. (Stony Brook, N.Y.)

276 An Improved Valve-Spreading Catheter for Producing Reversible Graded Acute Aortic Regurgitation

Ardehali, A.; Segal, J.; Cheitlin, M.D. (San Francisco, Calif.)

279 Echocardiographic Detection of Reversible Right Ventricular Strain in Patients with Acute

Pulmonary Embolism: Report of 2 Cases

Fang, B.-R.; Chiang, C.-W.; Lee, Y.-S. (Taipei) 283 Detection of Circulating Alpha-Actinin in Non-Insulin-Dependent Diabetics with Autonomic Dysfunction

Prados, J.; Melguizo, C; Aránega, A.E.; Escobar-Jimenez, F.; Cobo, V.; Aránega, A.

(Almería/Granada)

287 Age and Gender Differences in Left Ventricular Function among Patients with Stable

Angina and a Matched Control Group

A Report from the Angina Prognosis Study in Stockholm

Eriksson, S.V.; Björkander, I.; Held, C; Hjemdahl, P.; Forslund, L.; Rehnqvist, N.

(Danderyd/Stockholm)

294 Blood Flow Distribution in Necrotic versus Nonnecrotic Rabbit Hearts

Bianco, J.A.; Pyzalski, R.W.; Pyzalska, D.M.; Sebree, L.A.; Hegge, J.; Quintana, F.A. (Madison, Wise.)

300 Heart Rhythm in Patients with Neurofibromatosis Type 1

Malmcrona, R,; Zöller, M.; Rembeck, B. (Gothenburg) 303 Plasma Endothelin-1 Levels in

Takayasu's Arteritis

Akazawa, H.; Ikeda, U.; Kuroda, T.; Shimada, K. (Tochigi)

306 The Effect of Intra-Aortic Balloon Counterpulsation on Coronary Blood Flow Velocity

Distal to Coronary Artery Stenoses

Anderson, R.D.; Gurbel, P.A. (Baltimore, Md.)

313 Moexipril as Add-On Therapy to Hydrochlorothiazide in Moderate to Severe Hypotension

Stimpel, M.; Koch, B.; Dickstein, K. (Monheim/Stavanger)

Arrhythmias, Electrophysiology and Electrocardiography

319 Electrophysiological Effects of Propofol on the Normal Cardiac Conduction System

Pires, L.A.; Huang, S.K.S.; Wagshal, A.B.; Kulkarni, R.S. (Worcester, Mass.)

Congenital Heart Diseases

325 Congenital Coronary Fistulas in Children and Adults: Diagnosis, Surgical Technique and

Results

Carrel, T.; Tkebuchava, T.; Jenni, R.; Arbenz, U,; Turina, M. (Zurich)

Coronary Care

331 Frequency of Pulmonary Embolism in Patients Admitted with Chest Pain and Suspicion of

Acute Myocardial Infarction but in Whom this Diagnosis Is Ruled Out

Fruergaard, P.; Launbjerg, J.; Hesse, B. (Hillerød/Copenhagen)

Noninvasive and Diagnostic Cardiology

335 Value of Three-Dimensional Echocardiography as an Adjunct to Conventional

Transesophageal Echocardiography

Binder, T.; Globits, S.; Zangeneh, M.; Gabriel, H,; Röthy, W.; Glogar, D.; Maurer, G.;

Baumgartner, H. (Vienna)

343 Time Course of Changes in P-Wave Duration during Exercise

Pandya, A.; Ellestad, M.H.; Crump, R. (Long Beach, Calif.) 
347 Left Ventricular Systolic and Diastolic Function in Severe Obesity: A Radionuclide Study Ferraro, S.; Perrone-Filardi, P.; Desiderio, A.; Betocchi, S.; D’Alto, M.; Liguori, L.;

Trimigliozzi, P.; Turco, S.; Chiariello, M. (Naples)

354 Successful Treatment of Acute Myocardial Infarction by Thrombolytic Therapy in a Patient with Primary Antiphospholipid Antibody Syndrome

Ho, Y.-L.; Chen, M.-F.; Wu, C.-C; Chen, W.-J.; Lee, Y.-T. (Taipei)

358 Atypical Electrocardiogram and Echocardiogram in a Patient with Bland-White-Garland Syndrome in Association with Atrial Septal Defect

Nakagawa, M.; Kimura, K.; Watanabe, Y. (Shiga) 361 Acute Myocardial Infarction during

Pregnancy

Fujito, T.; Inoue, T,; Mizoguchi, K.; Hoshi, K.; Yamaguchi, H.; Morooka, S.; Numaguchi, M.;

Hayashi, M. (Saitama)

No. 5

General Cardiology

365 The Left Ventriculographic Pattern and Serial Electro-cardiographic Changes in

Hypertrophic Cardiomyopathy Patients with Giant Negative T Waves

Hata, S.; Shikawa, M.; Yamasa, T.; Miyahara, Y,; Kohno, S. (Nagasaki)

374 Clinical Features of Subjects with Mitral Valve Prolapse:

A Study with 24-Hour Ambulatory Blood Pressure Monitoring

Cassone, R.; Moroni, C; Parlapiano, C; Bondanini F.; Affricano, C. (Roma)

379 Spontaneous Echocardiographic Contrast in the Descending Thoracic Aorta

Zainea, M.A.; Karamali, A.M.; Grinberg, I.; Lee, H.; Duvernoy, W.F.C. (Southfield,

Mich./Detroit, Mich.)

General Cardiology, Review

384 Plaque Removal and Thrombus Dissolution with the Photoacoustic Energy of Pulsed-Wave Lasers - Biotissue Interactions and Their Clinical Manifestations

Topaz, O. (Richmond, Va.)

Arrhythmias, Electrophysiology and Electrocardiography

392 Use of Cardiac Troponin T, Creatine Kinase and 1st Isoform to Monitor Myocardial Injury

during Radiofrequency Ablation for Supraventricular Tachycardia

Shyu, K.-G.; Lin, J.-L.; Chen, J.-J.; Chang, H. (Taipei)

Invasive Cardiology and Cardiac Catheterization

396 Age- and Gender-Related Differences in Success, Major and Minor Complication Rates and the Duration of Hospitalization after Percutaneous Transluminal Coronary Angioplasty

Rozenman, Y.; Gilon, D.; Zelingher, J.; Sapoznikov, D.; Lotan, C; Mosseri, M.; Weiss, A.T.; Hasin, Y.; Gotsman, M.S. (Jerusalem)

Clinical Pharmacology

402 Evaluation of the Sympathetic Nervous System Using Heart Rate Variability and Plasma

Hormones in Hypertensive Patients Treated with Cilazapril and Atenolol

Campelo, M.; Polónia, J.; Serrão, P.; Cerqueira-Gomes, M. (Porto)

409 Analysis of Adverse Effects among Patients with Essential Hypertension Receiving and ACE Inhibitor or a Beta-Blocker

Rosenthal, J.; Bahrmann, H,; Benkert, K.; Baumgart, P.; Bönner, G.; Klein, G.; Neiss, A.;

Schnelle, K.; Frohlich, E.D. (Ulm/Freiburg/Münster/ Cologne/Munich/New Orleans, La.)

Coronary Care

415 Systemic Arterial Compliance Early and Late after a First Acute Myocardial Infarction 
Aakhus, S.; Bjørnstad, K,; Soma, J.; Skjaerpe, T.; Angelsen, B.A.J. (Trondheim)

423 Mortality, Place and Mode of Death and Reinfarction during a Period of 5 Years after Acute Myocardial Infarction in Diabetic and Non-Diabetic Patients

Herlitz, J.; Bang, A.; Karlson, B.W. (Göteborg)

Contents

Cardiology Vol. 87, 1996

$\mathrm{V}$

Diagnostic and Noninvasive Cardiology

Cardiac Surgery

429 Left-Ventricular Hypertrophy in the Elderly: Unreliability of ECG Criteria in 477 Subjects Aged 65 Years or More

The CArdiovascular STudy in the ELderly (CASTEL)

Casiglia, E.; Maniati, G.; Daskalakis, C; Colangeli, G.; Tramontin, P.; Ginocchio, G.; Spolaore,

P. (Padova/Castelfranco Veneto)

436 Diastolic Spectrum of Left-Ventricular Hypertrophy: The Impact of Etiology and Coronary Artery Disease on Doppler Transmitral Velocity

Tavli, T.; Ammar, A.; Wong, M. (Manisa/Zagazig/Los Angeles, Calif.)

Exercise and Cardiac Rehabilitation

443 Aerobic Capacity and Functional Classification of Patients with Severe Left-Ventricular

Dysfunction

Meyer, K.; Westbrook, S.; Schwaíbold, M.; Görnandt, L.; Lehmann, M.; Roskamm, H. (Ulm)

Case Report

450 Transesophageal Echocardiography during Surgical Closed Mitral Commissurotomy

Chandra bose Reddy, S.; Goel, A.K.; Jain, P.; Sharma, R.; Wasir, H.S.; Venugopal, P. (New

Delhi)

449 Announcement

509 Impact of Triiodothyronine on the Survival of High-Risk Patients Undergoing Open Heart

Surgery

Novitzky, D.; Fontanet, H.; Snyder, M.; Coblio, N; Smith, D.; Parsonnet, V. (Tampa,

Fla./Newark, N.J.)

Cardiovascular Surgery

516 Hypothermic Cardioplegic Arrest Is Associated with Increased Myocardial Adenosine

Shortt, K.G.; Stahl, R.F.; Soller, B.R.; Belle Isle, J.M.; Auerbach, A.H.; Hsi, C.C. (Worcester, Mass.)

Clinical Pharmacology

524 Effect of Antihypertensive Treatment on Lipids and Fibrinogen: Greek Multicentre Study of Cillazapril

Tsagadopoulos, D.; Antonakoudis, H.; Makris, T.; Votteas, V.; Vyssoulis, G.; Manolis, A.;

Babalis, D.; Lefkos, N.; Achimastos, A.; Toutouzas, P. (Athens)

Coronary Care

529 Survival, Mode of Death, Reinfarction and Use of Medication during a Period of 5 Years after Acute Myocardial Infarction in Different Age Groups

Herlitz, J,; Karlson, B.W.; Bang, A.; Sjölin, M. (Göteborg)

Noninvasive and Diagnostic Cardiology 
No. 6

Reviews

453 Lipid-Lowering Trials: What Have They Taught Us about Morbidity and Mortality?

Gotto, A.M., Jr. (Houston, Tex.) 458 Non-Lipid-Related Effects of 3-Hydroxy-3-Methylglutaryl

Coenzyme A Reductase Inhibitors

Corsini, A.; Bernini, F.; Quarato, P.; Donetti, E.; Bellosta, S.; Fumagalli, R.; Paoletti, R.; Soma, V.M.R. (Parma)

469 Targeted Prevention of Coronary Artery Disease:

Pharmacological Considerations in Multimodality Treatment

Shviro, I.; Leitersdorf, E. (Jerusalem)

General Cardiology

476 Plasma Cytokine Levels in Cardiac Chambers of Patients with Mitral Stenosis with

Congestive Heart Failure

Ikeda, U.; Yamamoto, K.; Akazawa, H.; Hojo, Y.; Ohkawa, F.; Fujikawa, H.; Sekiguchi, H.;

Shimada, K. (Tochigi)

481 Predictors of Sudden Cardiac Death for Patients with Chagas' Disease: A Hospital-Derived

Cohort Study

Bestetti, R.B.; Dalbo, C.M.R.; Arruda, C.A.; Filho, D.C.; Freitas, O.C. (Uberaba/Ribeirão Preto) 488 HLA-DR2 Antigen Linkage in Patients with Apical Hypertrophic Cardiomyopathy in Japan Kishimoto, C; Takada, H.; Hiraoka, Y.; Suzaki, M.; Maruya, E.; Tomioka, N.

(Toyama/Himekawa/Kyoto/Ohtsu)

492 Heart Rate Variability in Patients with Sleep-Related Breathing Disorders

Bauer, T.; Ewig, S.; Schäfer, H.; Jelen, E.; Omran, H.; Lüderitz, B. (Bonn)

497 Dyslipidemia and Coronary Artery Disease. Prevalence and Treatment in Patients Referred for Coronary Arteriography

Rohold, A.; Haastrup, B.; Larsen, S.; Hansen, A.B.; Larsen, M.L.; Haghfelt, T. (Odense)

502 Does Cigarette Smoking Paradoxically Increase Survival in Idiopathic Dilated

Cardiomyopathy? The Washington, D.C., Dilated Cardiomyopathy Study

Metayer, C; Coughlin, S.S.; Mather, F.J. (New Orleans, La.)

537 Interference of Mitral Valve Stenosis with Left Ventricular Diastole and Left Atrial

Appendage Flow

Lin, J.-M.; Hsu, K.-L.; Hwang, J.-J.; Li, Y.-H.; Tseng, Y.-Z. (Taipei)

545 Doppler Echocardiographic Estimation of the Pressure Gradient in Aortic Stenosis. An

Updated Assessment of the Technique Used in Clinical Practice in 249 Patients Schroeder, A.P.; Egeblad, H.; Østergaard Kristensen, B. (Aarhus-Skejby)

552 Preliminary Report: Evaluation of Three-Dimensional Echocardiographic Volumetry by

Simultaneous Thermal Dilution in Coronary Heart Disease

Müller, S,; Bartel, T.; Baumann, G.; Erbel, R. (Essen/Berlin)

560 Simultaneous Evaluation of the Doppler-Derived Transmitral Flow Velocity Waveform and Left Ventricular Isovolumic Relaxation Time in Patients with Coronary Artery Disease

Hashimoto, T.; Ohte, N.; Narita, H.; Kobayashi, K.; Akita, S.; Fujinami, T. (Nagoya)

Case Report

566 Massive Cardiac Involvement by Malignant Lymphoma

Lynch, M.; Cobbs, W., Jr.; Miller, R.L.; Martin, R.P. (Atlanta, Ga.)

Letter to the Editor 
569 Losartan and Reversible Psychosis

Ahmad, S. (Fairmont, W. Va.)

571 Author Index Vol. 87573 Subject Index Vol. 87

VI

Cardiology Vol. 87, 1996

Contents 